\title{
Co-ingestion of carbohydrate and whey protein isolates enhance PGC-1a mRNA expression: a randomised, single blind, cross over study
}

\author{
Karen M Hill ${ }^{1}$, Christos G Stathis ${ }^{1,2}$, Esther Grinfeld ${ }^{1}$, Alan Hayes ${ }^{1,2}$ and Andrew J McAinch ${ }^{1,2^{*}}$
}

\begin{abstract}
Background: Whey protein isolates (WPI) supplementation is known to improve resistance training adaptations. However, limited information is available on the effects of WPI plus carbohydrate (CHO) supplementation on endurance training adaptations.

Method: Six endurance trained male cyclists and triathletes (age $29 \pm 4$ years, weight $74 \pm 2 \mathrm{~kg}, V_{2} \max 63 \pm 3 \mathrm{ml}$ oxygen $\mathrm{kg}^{-1} \cdot \mathrm{Min}^{-1}$, height $183 \pm 5 \mathrm{~cm}$; mean \pm SEM) were randomly assigned to one of two dietary interventions in a single blind cross over design; $\mathrm{CHO}$ or $\mathrm{CHO}+$ WPI. Each dietary intervention was followed for 16 days which included the last 2 days having increased $\mathrm{CHO}$ content, representing a $\mathrm{CHO}$ loading phase. The dietary interventions were iso-caloric and carbohydrate content matched. On completion of the dietary intervention, participants performed an exercise bout, consisting of cycling for 60 min at $70 \% \mathrm{VO}_{2}$ max, followed by time trial to exhaustion at $90 \% \mathrm{VO}_{2}$ max and recovered in the laboratory for 6 hours. Blood samples and muscle biopsies were taken at various time points at rest and through the exercise trial and recovery.
\end{abstract}

Results: Compared to $\mathrm{CHO}, \mathrm{CHO}+\mathrm{WPI}$ increased plasma insulin during recovery at 180 mins $(\mathrm{P}<0.05)$ and peroxisome proliferator-activated receptor gamma coactivator-1 alpha (PGC-1a) mRNA expression at the end of 6 hours of recovery $(P<0.05)$. Muscle glycogen did not differ between the two trials.

Conclusion: This study showed co-ingestion of $\mathrm{CHO}+$ WPI may have beneficial effects on recovery and adaptations to endurance exercise via, increased insulin response and up regulation of PGC-1a mRNA expression.

Keywords: Muscle protein synthesis, Protein supplementation, Endurance exercise adaptations, Mitochondrial biogenesis

\section{Background}

Optimal nutrition is not only required for normal physiological functioning, but the nutritional status of an endurance athlete can negatively or positively impact their sporting performance [1]. Nutritional requirements of endurance athletes include higher energy needs to fuel exercise and replace glycogen stores and increased protein intake to support muscle protein turnover. During endurance exercise major disturbances to cellular homeostasis, substrate stores and utilization occur in the muscle [2]. Recovery from endurance

\footnotetext{
* Correspondence: andrew.mcainch@vu.edu.au
'Biomedical and Lifestyle Diseases Unit, College of Health and Biomedicine,

'Biomedical and Lifestyle Diseases Unit, College of Health and Biomedicine, Victoria University, PO Box 14428, Melbourne, VIC 8001, Australia ${ }^{2}$ Institute of Sport, Exercise and Active Living, Victoria University, Melbourne, Australia
}

(c) 2013 Hill et al.; licensee BioMed Central Ltd. This is an Open Access article distributed under the terms of the Creative Commons Attribution License (http://creativecommons.org/licenses/by/2.0), which permits unrestricted use, distribution, and reproduction in any medium, provided the original work is properly cited.

training sessions is fundamental, as the muscle damage caused during exercise partly due to muscle contraction and hormonal changes that result in the breakdown of muscle protein, continues once exercise is ceased [3]. This damage can impair subsequent muscle function, delivery of nutrients, glycogen resynthesis rates and impair protein synthesis pathways [3].

Repeated bouts of endurance exercise result in structural, metabolic and physiological adaptations that enable improved performance [4]. Long term adaptations are a cumulative result of successive training sessions and the post exercise period is critical in allowing these processes [2]. During recovery the activation of several major signalling pathways occurs in the first few hours before returning to baseline within 24 hours [2]. 
Recovery from endurance exercise requires muscle glycogen stores to be replenished and damaged muscle to be repaired [5].

Nutrition is a key component supporting heavy training and competition [6]. The primary fuel source during endurance events is muscle glycogen $[7,8]$. It is well documented that depletion of intramuscular glycogen stores can limit performance during prolonged exercise [9]. Maximising pre-exercise glycogen levels through carbohydrate loading has become well practiced by athletes, in addition to refuelling immediately post exercise to optimise muscle glycogen restoration [10]. However, carbohydrates alone are not enough to stimulate significant protein synthesis and the adaptive response to endurance exercise [11].

Protein is an extremely important substrate, due to the influence it exerts over the regulation rates of muscle protein synthesis (MPS) and the subsequent effects on the phenotype of skeletal muscle [12]. Muscle adaptations depend on the availability of sufficient protein [2]. The type of protein consumed can affect the recovery process due to differences in the digestion rate of the protein and concentration of proteins [11]. Micellar casein proteins are released from the stomach slower than whey protein isolates. Therefore, whey produces a faster, transient increase in plasma amino acid concentration and potentially an improved availability of amino acids [13]. Whey protein isolates, compared with other protein sources, are more effective at promoting protein synthesis following resistance exercise due to the high concentration of essential and branched chain amino acids [14].

The mode of exercise influences the subsequent muscle adaptations, with endurance exercise primarily resulting in increased muscle oxidative capacity and resistance exercise predominantly resulting in muscle hypertrophy [15]. Endurance training improves skeletal muscle adaptations by increases in activators of mitochondrial biogenesis such as peroxisome proliferator-activated receptor gamma coactivator-1 alpha (PGC-1 $\alpha)[16,17]$.

The regulation of protein synthesis involves several signalling pathways. These are influenced by amino acids, insulin and mechanical stimulation [18]. A large body of research exists which demonstrates the benefits of protein supplementation with resistance exercise $[14,19,20]$. However, limited research exists on the benefits of protein supplementation for athletes undertaking endurance training. In particular, the effects of co-ingestion of whey protein isolates and carbohydrate on endurance exercise recovery and $\mathrm{PGC}-1 \alpha$ pathway.

The present study investigates 2 weeks of co-ingestion of whey protein isolates plus ample carbohydrate $(\mathrm{CHO}+$ WPI) on endurance performance and recovery, compared to an isocaloric, carbohydrate content matched group (CHO). We hypothesized that $\mathrm{CHO}+$ WPI will improve performance and recovery by increasing muscle glycogen levels and facilitating adaptive response, compared to $\mathrm{CHO}$ alone.

\section{Methods}

\section{Subjects}

Six healthy endurance trained cyclists and triathletes volunteered to complete the study (age $29 \pm 4$ years, weight $74 \pm 2 \mathrm{~kg}, \mathrm{VO}_{2 \max } 63 \pm 3 \mathrm{ml}$ oxygen $\mathrm{kg}^{-1} \cdot \mathrm{min}$, height $183 \pm 5 \mathrm{~cm}$; mean \pm SEM). This study was approved by Victoria University Human Research Ethics Committee. The purpose and potential risks of the experiment were explained to participants prior to them providing written informed consent. Participants completed a standard medical questionnaire prior to commencing trials. Involvement in this study required attainment of a maximal oxygen consumption of at least $60 \mathrm{ml}$ oxygen $\mathrm{kg}^{-1} \mathrm{~min}^{-1}$ and not having consumed whey protein supplements in the 12 weeks prior to the study.

\section{Preliminary measurements}

Participants reported to the laboratory for a $\mathrm{VO}_{2 \max }$ cycling test on a cycle ergometer. The exercise test consisted of $3 \mathrm{~min}$ at 3 sub-maximal workloads followed by subsequent increments of 25 watts (W) every min until fatigue. During the test, subjects' heart rate (HR) was monitored and respiratory gases collected continuously for gas analysis. Respiratory gas measurements were measured using open circuit spirometry indirect calorimetry using a metabolic cart.

Data obtained from participants $\mathrm{VO}_{2 \max }$ was used to calculate their workloads $\left(70 \%\right.$ and $90 \% \mathrm{VO}_{2 \max }$ ) for the exercise trial. A standard curve was constructed from the 3 sub-maximal workloads and $\mathrm{VO}_{2}$. The predicted $\mathrm{VO}_{2 \text { max }}$ was then used to calculate the percentage workloads (W) according to the linear equation generated by the standard curve.

On completion of testing, participants were introduced to the dietary regimes and trial procedures used during the study. It was requested that participants maintain their training throughout the dietary interventions and washout period.

\section{Study design}

A randomised, single blind cross over design was used to test the effect of whey protein isolates supplementation on endurance performance and recovery. The dietary interventions were randomly assigned and participants were blinded to the intervention, by matching $\mathrm{CHO}$ beverage and $\mathrm{CHO}+$ WPI beverage for taste, smell and appearance. Each dietary protocol was followed for a total of $16 \mathrm{~d}$ (14 $\mathrm{d}$ followed by $2 \mathrm{~d} \mathrm{CHO}$ loading phase) with a 4 week wash out period to separate the dietary interventions. 
Table 1 Carbohydrate (CHO), protein (PRO) and fat content of dietary interventions for carbohydrate (CHO) and carbohydrate and whey protein isolates (CHO + WPI)

\begin{tabular}{|c|c|c|c|c|c|c|}
\hline \multicolumn{4}{|c|}{14 days } & \multicolumn{3}{|c|}{2 day $\mathrm{CHO}$ loading } \\
\hline & $\begin{array}{l}\mathrm{CHO}\left(\mathrm{g} \cdot \mathrm{kg}^{-1} \cdot \mathrm{bw} /\right. \\
\text { day) }\end{array}$ & $\begin{array}{l}\text { PRO }\left(\mathbf{g} \cdot \mathbf{k g}^{-1} \cdot \mathbf{b w} /\right. \\
\text { day) }\end{array}$ & $\begin{array}{l}\text { Fat }\left(\mathrm{g} \cdot \mathrm{kg}^{-1} \cdot \mathrm{bw} /\right. \\
\text { day) }\end{array}$ & $\begin{array}{l}\mathrm{CHO}\left(\mathrm{g} \cdot \mathrm{kg}^{-1} \cdot \mathrm{bw} /\right. \\
\text { day) }\end{array}$ & $\begin{array}{l}\text { Pro }\left(\mathbf{g} \cdot \mathbf{k g}^{-1} \cdot \mathbf{b w} /\right. \\
\text { day) }\end{array}$ & $\begin{array}{l}\text { Fat }\left(\mathrm{g} \cdot \mathrm{kg}^{-1} \cdot \mathrm{bw} /\right. \\
\text { day) }\end{array}$ \\
\hline $\mathrm{CHO}$ & 8 & 1.2 & 1.7 & 10 & 1.2 & 1.7 \\
\hline $\begin{array}{l}\mathrm{CHO}+ \\
\text { WPI }\end{array}$ & 8 & 2.4 & 1.1 & 10 & 2.4 & 1.1 \\
\hline
\end{tabular}

Dietary interventions were isocaloric and $\mathrm{CHO}$ content matched (see Table 1 for nutritional value of diets). Diets were isocaloric through altering the amount of fat consumed, however the total fat content in the $\mathrm{CHO}$ group still contributed less than $30 \%$ of total energy. The extra $1.2 \mathrm{~g}^{\cdot} \mathrm{kg}^{-1}$ bw/d of protein was supplemented with whey protein isolates (Table 2) and was provided in a readymade sports drink (Table 3; provided courtesy of MG Nutritionals, Australia). The CHO trial consumed the sports drink, minus the WPI. On training days participants were instructed to consume the drink during and after training sessions and on non-training days to consume any time throughout the day.

Participants were provided with all their meals and snacks throughout the duration of the dietary interventions to ensure consistency in energy and macronutrient levels and to assist with compliance. Additionally, participants were provided with check-off sheets to facilitate documenting food intake.

Table 2 Amino acid profile of whey protein isolate supplement used in the sports beverages

\begin{tabular}{ll}
\hline Component & \% w/w \\
\hline Alanine & 5.2 \\
Arginine & 2.7 \\
Aspartic acid & 10.6 \\
Cystine & 1.9 \\
Glutamic acid & 17.5 \\
Glycine & 1.3 \\
*Histidine & 1.6 \\
* Isoleucine & 6.1 \\
* Leucine & 15.3 \\
* Lysine & 10.4 \\
* Methionine & 2.6 \\
* Phenylalanine & 3.4 \\
Proline & 4.4 \\
Serine & 3.2 \\
* Threonine & 4.4 \\
* Tryptophan & 2.3 \\
Tyrosine & 4.1 \\
* Valine & 5.2 \\
\hline
\end{tabular}

* indicates essential amino acid.

\section{Experimental trials}

After completing the $16 \mathrm{~d}$ dietary intervention $(\mathrm{CHO}$ or $\mathrm{CHO}+\mathrm{WPI}$ ), participants reported to the laboratory after an overnight fast. The exercise trial was completed on a cycle ergometer which consisted of cycling for $60 \mathrm{~min}$ at $70 \% \mathrm{VO}_{2 \max }$ followed by 2 min break, then cycling to fatigue at $90 \% \mathrm{VO}_{2}$ max. Following this, subjects recovered in the laboratory for $6 \mathrm{~h}$.

During the $6 \mathrm{~h}$ recovery period participants followed the dietary intervention they had been on prior to their exercise trial $(\mathrm{CHO}$ or $\mathrm{CHO}+\mathrm{WPI})$. If they were consuming the $\mathrm{CHO}$ diet, they consumed $4 \mathrm{~g} \mathrm{~kg}^{-1}$. bw carbohydrate, $0.6 \mathrm{~g} \cdot \mathrm{kg}^{-1}$ bw fat and $0.4 \mathrm{~g} \cdot \mathrm{kg}^{-1}$. bw protein. Following the $\mathrm{CHO}+\mathrm{WPI}$ diet participants consumed $4 \mathrm{~g} \cdot \mathrm{kg}^{-1}$. bw carbohydrate, $0.4 \mathrm{~g} \cdot \mathrm{kg}^{-1}$. bw fat and $1.1 \mathrm{~g}^{\cdot} \mathrm{kg}^{-1}$. bw protein during the first $3 \mathrm{~h}$ of the $6 \mathrm{~h}$ recovery period. The protein source during recovery for the $\mathrm{CHO}+$ WPI group was predominantly whey protein isolate provided in the sports drinks $\left(0.7 \mathrm{~g} \mathrm{~kg}^{-1}\right.$. bw). Recovery nutrition was carbohydrate matched and isocaloric by altering the fat content in the breakfast provided.

Venous blood samples were taken from an antecubital vein at rest, every 20 min during cycling at $70 \% \mathrm{VO}_{2}$ max and on completion of cycling at $90 \% \mathrm{VO}_{2} \max$. Blood was taken every $10 \mathrm{~min}$ during the first hour and every hour after this for the remaining $6 \mathrm{~h}$ of recovery. Plasma was subsequently analysed for glucose and insulin concentration.

Muscle biopsies were taken at rest, the end of $60 \mathrm{~min}$ cycling at $70 \% \mathrm{VO}_{2}$ max during the 2 min break, on completion of cycling to fatigue at $90 \% \mathrm{VO}_{2} \max$ and the end of $6 \mathrm{~h}$ recovery. Muscle biopsies were obtained from the vastus lateralis. Leg selection was random and in the second trial the contra lateral leg was biopsied. The biopsy site was prepared under local anaesthesia (1\% xylocaine) and an incision was made at the site in the skin (one incision per sample) prior to exercise. Muscle samples were taken using the Bergstrom [21] procedure as modified for suction [22]. Muscle samples were frozen in liquid nitrogen for subsequent analysis.

One portion of frozen muscle was used to analyse muscle glycogen. Muscle samples were freeze dried and powdered and any obvious blood and connective tissue removed. The samples were weighed and tissue 
Table 3 Nutritional information for the sports beverage

\begin{tabular}{lcc}
\hline Average quantity per $\mathbf{1 0 0} \mathbf{~} \mathbf{l}$ & CHO & WPI \\
\hline Energy & $119 \mathrm{~kJ}$ & $180 \mathrm{~kJ}$ \\
Protein & $0 \mathrm{~g}$ & $3.6 \mathrm{~g}$ \\
Fat & $0 \mathrm{~g}$ & $0 \mathrm{~g}$ \\
Carbohydrate & $7 \mathrm{~g}$ & $7 \mathrm{~g}$ \\
Sodium & $30 \mathrm{mg}$ & $30 \mathrm{mg}$ \\
Potassium & $40 \mathrm{mg}$ & $40 \mathrm{mg}$ \\
\hline
\end{tabular}

extracted in acid and neutralized in preparation for determination of muscle glycogen. Muscle glycogen was measured using an enzymatic assay adapted for fluorometry [23].

Messenger RNA (mRNA) expression of glycogen synthase, PGC- $1 \alpha$ and adenosine monophosphate-activated protein kinase-alpha 2 (AMPK- $\alpha 2)$ was analyzed by 'real-time' PCR. 'Real-time' PCR was conducted using MyiQ $^{\mathrm{TM}}$ single colour 'real-time' PCR detection system (Bio-Rad Laboratories, Hercules, CA) with $\mathrm{iQ}^{\mathrm{TM}}$ SYBR Green Supermix (Bio-Rad Laboratories, Hercules, CA) as the fluorescent agent. Forward and reverse oligonucleotide primers for the genes of interest were designed using OligoPerfect $^{\mathrm{TM}}$ Suite (Invitrogen, Melbourne, Australia) with sequences obtained from GenBank. Selective gene homology was confirmed with BLAST. To compensate for variations in RNA input amounts and to reverse transcriptase efficiency mRNA abundance of housekeeping genes, GAPDH and cyclophilin was quantified and the expression of the genes of interest was normalised to this (Forward and reverse oligonucleotide primers are shown in Table 4). 'Real-time' PCR reactions (total volume $20 \mu \mathrm{l}$ ) were primed with $2.5 \mathrm{ng}$ of cDNA and were run for 40 or 50 cycles of $95^{\circ} \mathrm{C}$ for $15 \mathrm{sec}$ and $60^{\circ} \mathrm{C}$ for $60 \mathrm{sec}$. Relative changes in mRNA abundance was quantified using the $2^{-\Delta \Delta C T}$ method as previously detailed [24] and reported in arbitrary units.

\section{Statistical analysis}

All data is expressed as means \pm standard error of the mean (SEM). Two way repeated measures ANOVA (treatment $\times$ time) was used to compare means, using GraphPad Prism (version 5.01, GraphPad Software Inc., San Diego, CA, USA). Significance was set at $\mathrm{P}<0.05$.
When significance was detected Bonferoni post hoc test was used to determine where significance occurred.

\section{Results}

Time to fatigue was not significantly different between $\mathrm{CHO}(11: 14 \pm 1: 05 \mathrm{~min})$ and $\mathrm{CHO}+$ WPI (10:05 \pm 1:30 min). Plasma glucose concentration is presented in Figure 1. For both $\mathrm{CHO}$ and $\mathrm{CHO}+\mathrm{WPI}$ groups, plasma glucose was significantly increased during cycling at $90 \%$ $\mathrm{VO}_{2}$ max and remained elevated compared to rest until 40 min during recovery, with the $\mathrm{CHO}$ group remaining elevated until $60 \mathrm{~min}$ during recovery. No differences in plasma glucose were detected between the trials at any time point. Plasma insulin concentration (Figure 2) for the $\mathrm{CHO}$ trial increased compared to rest, from $40 \mathrm{~min}$ to 180 min during recovery $(\mathrm{P}<0.05)$. The $\mathrm{CHO}+\mathrm{WPI}$ trial increased compared to rest, from $30 \mathrm{~min}$ to 180 min during recovery $(\mathrm{P}<0.05)$. The $\mathrm{CHO}+\mathrm{WPI}$ trial had significantly elevated insulin levels at $180 \mathrm{~min}$ during the recovery period $(\mathrm{P}<0.05)$ compared to $\mathrm{CHO}$ trial.

Muscle glycogen content (Figure 3) was similar for $\mathrm{CHO}$ and $\mathrm{CHO}+\mathrm{WPI}$ trials at rest. Following exercise and $6 \mathrm{~h}$ recovery period both trials were lower than rest $(\mathrm{P}<0.05)$. The $\mathrm{CHO}+\mathrm{WPI}$ trial was significantly increased from the end of cycling at $90 \% \mathrm{VO}_{2}$ max to the end of $6 \mathrm{~h}$ recovery, whereas the $\mathrm{CHO}$ trial did not show this increase. This occurred with no difference in mRNA expression of glycogen synthase between $\mathrm{CHO}$ and $\mathrm{CHO}+$ WPI trials (Figure 4).

AMPK- $\alpha 2$ mRNA expression (Figure 5) was similar for $\mathrm{CHO}$ and $\mathrm{CHO}+$ WPI trials. Following cycling at $90 \% \mathrm{VO}_{2}$ max and end of $6 \mathrm{~h}$ recovery, the $\mathrm{CHO}$ trial was lower compared to rest $(\mathrm{P}<0.05)$. PGC-1 $\alpha$ mRNA expression (Figure 6) was significantly higher at the end of $6 \mathrm{~h}$ recovery compared to all other time points in the $\mathrm{CHO}+\mathrm{WPI}$ trial $(\mathrm{P}<0.05)$. Following $6 \mathrm{~h}$ recovery the $\mathrm{CHO}+$ WPI trial was significantly higher $(\mathrm{P}<0.05)$ compared to the isocaloric carbohydrate matched $\mathrm{CHO}$ trial.

\section{Discussion}

Protein is considered a key nutritional component for athletic success, however there appears to be a lack of

Table 4 Oligonucleotide primers for 'Real - Time' PCR primers

\begin{tabular}{|c|c|c|c|}
\hline \multirow[t]{2}{*}{ Human genes } & \multirow{2}{*}{$\begin{array}{l}\text { Accession } \\
\text { number }\end{array}$} & \multirow{2}{*}{$\frac{\text { Forward primer }}{\left(5^{\prime}-3^{\prime}\right)}$} & \multirow{2}{*}{$\begin{array}{l}\text { Reverse primer } \\
\left(5^{\prime}-3^{\prime}\right)\end{array}$} \\
\hline & & & \\
\hline Cyclophilin & NM_021130.3 & CATCTGCACTGCCAAGACTGA & TTCATGCCTTCTITCACTITGC \\
\hline GAPDH & NM_002046.3 & CAACGACCACTITGTCAAGC & TTACTCCTTGGAGGCCATGT \\
\hline AMPK-a2 & NM_006252.3 & AACTGCAGAGAGCCATTCACTाT & GGTGAAACTGAAGACAATGTGCTT \\
\hline PGC-1a & NM_013261.3 & CAAGCCAAACCAACAACПTTATCTCT & CACACTTAAGGTGCGTTCAATAGTC \\
\hline Glycogen synthase & NM_002103.4 & GCTCCCTGTGGACTATGAGG & ATTCCCATAACCGTGCACTC \\
\hline
\end{tabular}




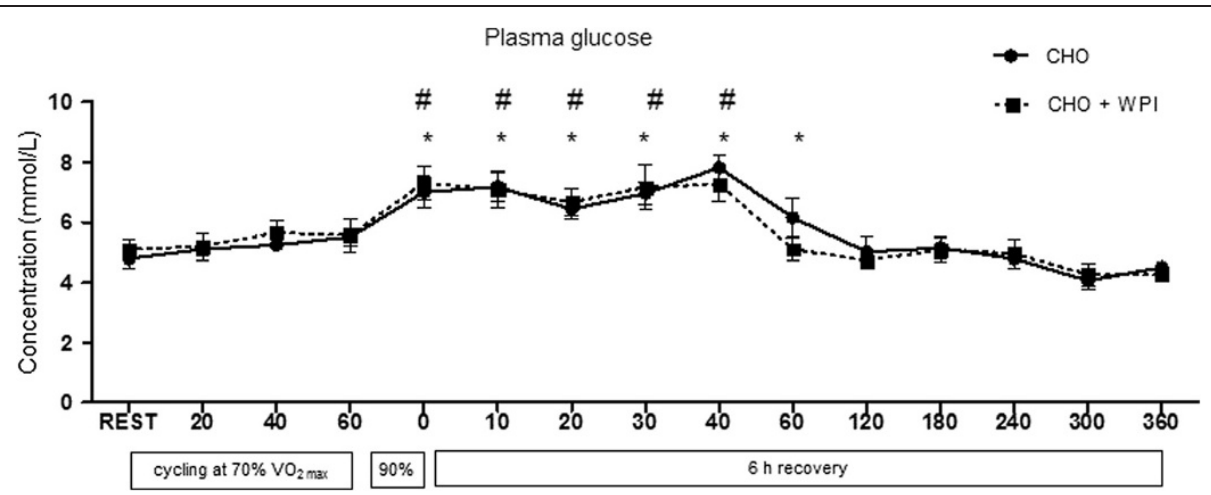

Figure 1 Plasma glucose concentration for carbohydrate $(\mathrm{CHO})$ and carbohydrate and whey protein isolates (CHO + WPI) trials. The exercise trial day consisted of 60 min cycling at $70 \% \mathrm{VO}_{2}$ max, with blood samples taken at rest and every 20 min (rest, 20, 40, 60). This was followed by time to fatigue at $90 \% \mathrm{VO}_{2}$ max and blood was taken on completion of this effort (0). The $6 \mathrm{~h}$ recovery consisted of blood taken regularly for the first $\mathrm{h}(10,20,30,40,60)$ and every 60 min after that $(120,180,240,300,360)$. Both $\mathrm{CHO}$ and CHO + WPI trials were significantly increased on completion of cycling at $90 \% \mathrm{VO}_{2}$ max and remained elevated compared to rest until 40 min during recovery in the $\mathrm{CHO}+\mathrm{WPI}$ trial (\# $P<0.05)$. Whilst the $\mathrm{CHO}$ group remained elevated compared to rest until 60 min during recovery $\left({ }^{*} P<0.05\right)$. Values are means $\pm S E M(n=6)$.

information regarding the effect of combined $\mathrm{CHO}$ and protein supplementation on exercise adaptations during recovery. This study compared 2 weeks co-ingestion of whey protein isolates supplementation combined with a high carbohydrate diet with an iso-caloric carbohydrate matched diet in endurance athletes. Protein supplementation with adequate carbohydrate availability, included in a regular training program, did not influence intense aerobic cycling performance or pre- and post-exercise muscle glycogen levels. However, increases in plasma insulin and muscle PGC-1 $\alpha$ mRNA expression with $\mathrm{CHO}+$ WPI supplementation compared to $\mathrm{CHO}$ alone indicates a potential for improved adaptations to training following supplementation.

Resting muscle glycogen levels were comparable with previously published carbohydrate loading protocols
[25]. Supplementation with whey protein isolates does not further increase resting muscle glycogen levels when adequate $\mathrm{CHO}\left(8 \mathrm{~g} \cdot \mathrm{kg}^{-1}\right.$ bw/day $)$ is consumed on a daily basis, followed by $\mathrm{CHO}$ loading prior to competition. However, glycogen resynthesis at the end of $6 \mathrm{~h}$ recovery was enhanced for the $\mathrm{CHO}+$ WPI trial and not the $\mathrm{CHO}$ trial. Earlier studies have shown co-ingestion of whey proteins with carbohydrate consumed during exercise and recovery period to augment muscle glycogen synthesis during the recovery period [26-28]. These studies used suboptimal levels of carbohydrate $\left(<0.8 \mathrm{~g}^{\cdot} \mathrm{kg}^{-1} \cdot \mathrm{bw} / \mathrm{h}\right)$ ingestion required for maximal glycogen synthesis rates during recovery, suggesting co-ingestion of $\mathrm{CHO}+$ WPI may only be beneficial for muscle glycogen resynthesis when insufficient $\mathrm{CHO}$ is consumed. However, the current study has also shown benefits of the addition of

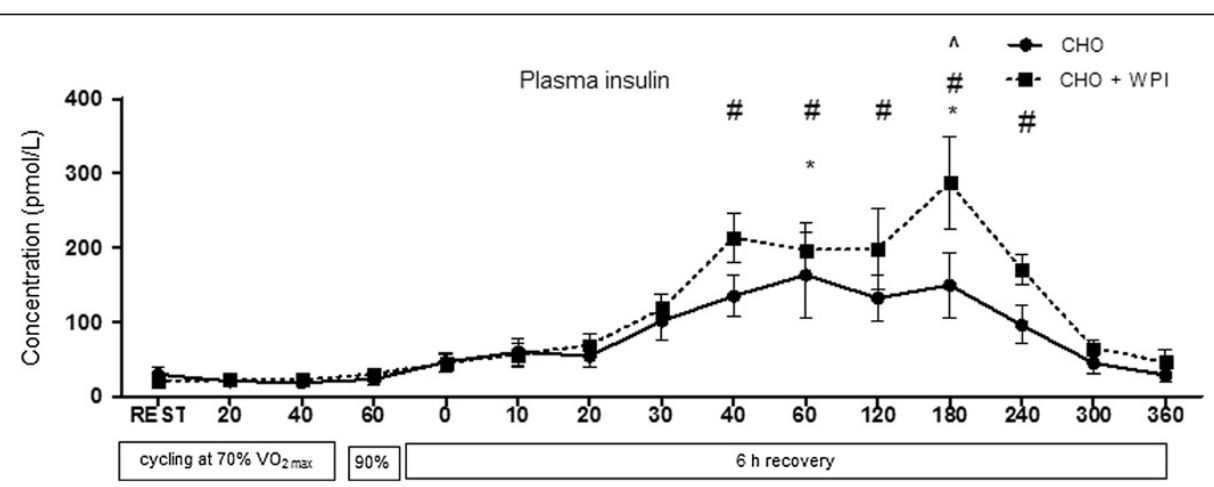

Figure 2 Plasma insulin concentration for carbohydrate $(\mathrm{CHO})$ and carbohydrate and whey protein isolates $(\mathrm{CHO}+\mathrm{WPI})$ trials. The exercise trial day consisted of 60 min cycling at $70 \% \mathrm{VO}_{2 \text { max }}$, with blood samples taken at rest and every 20 min (rest, 20, 40, 60). This was followed by time to fatigue at $90 \% \mathrm{VO}_{2} \max$ and blood was taken on completion of this effort (0). The $6 \mathrm{~h}$ recovery consisted of blood taken regularly for the first $h(10,20,30,40,60)$ and every 60 min after that $(120,180,240,300,360)$. Both trials, CHO $\left(^{*} P<0.05\right)$ and CHO + WPI (\# $\mathrm{P}<0.05)$, were significantly elevated compared to rest, with $\mathrm{CHO}+$ WPI significantly higher than $\mathrm{CHO}$ at $180 \mathrm{~min}(\wedge \mathrm{P}<0.05)$ during the recovery period, before returning to resting levels at $240 \mathrm{~min}$. Values are means \pm SEM $(n=6)$. 


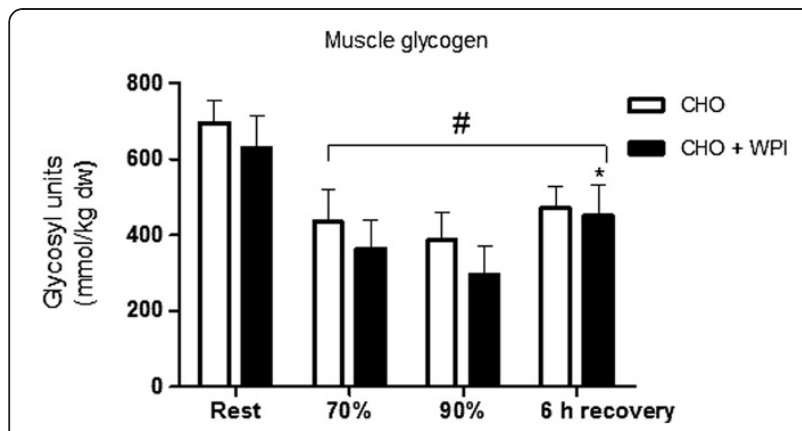

Figure 3 Muscle glycogen concentration following the 16 day dietary intervention and exercise trial day, which consisted of a resting (rest) muscle biopsy, another following 60 min cycling at $70 \% \mathrm{VO}_{2} \max (70 \%)$, time to fatigue at $90 \% \mathrm{VO}_{2} \max (90 \%)$ and at the end of $6 \mathrm{~h}$ recovery ( $6 \mathrm{~h}$ recovery). Carbohydrate $(\mathrm{CHO})$ and carbohydrate and whey protein isolates $(\mathrm{CHO}+\mathrm{WPI})$ trial were similar at rest. All time points following exercise were lower than rest in both trials (\# $\mathrm{P}<0.05)$. CHO + WPI trial was increased from $90 \% \mathrm{VO}_{2 \max }$ to end of $6 \mathrm{~h}$ recovery $\left({ }^{*} P<0.05\right)$. Values are means $\pm \operatorname{SEM}(n=6)$.

whey protein isolates even when optimal $\mathrm{CHO}$ is ingested.

Jentjens et al. [21] found co-ingestion of an amino acid mixture in combination with a large carbohydrate intake $\left(1.2 \mathrm{~g} \cdot \mathrm{kg}^{-1} \cdot \mathrm{bw} / \mathrm{h}\right)$ during recovery accentuates plasma insulin concentrations. The current study demonstrated increased insulin at $180 \mathrm{~min}$ of recovery following ingestion of the $\mathrm{CHO}+$ WPI sports beverage and a sustained elevation of insulin levels over a longer time. Whey protein isolates are insulinotrophic (the ability to stimulate the production of insulin) compared to caseins and other proteins of vegetable origin $[29,30]$. Whey protein isolates have been shown to induce an insulin response independent of carbohydrate co-ingestion [31].

Previous studies have suggested increased insulin levels to be one of the main mechanisms to increase muscle glycogen levels, via stimulation of glucose transporters in the muscle to increase glucose uptake along

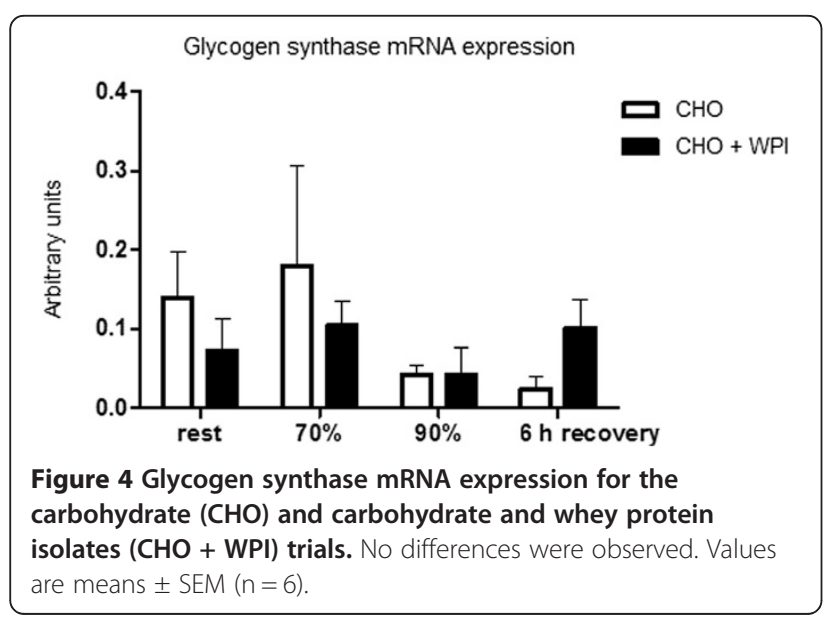

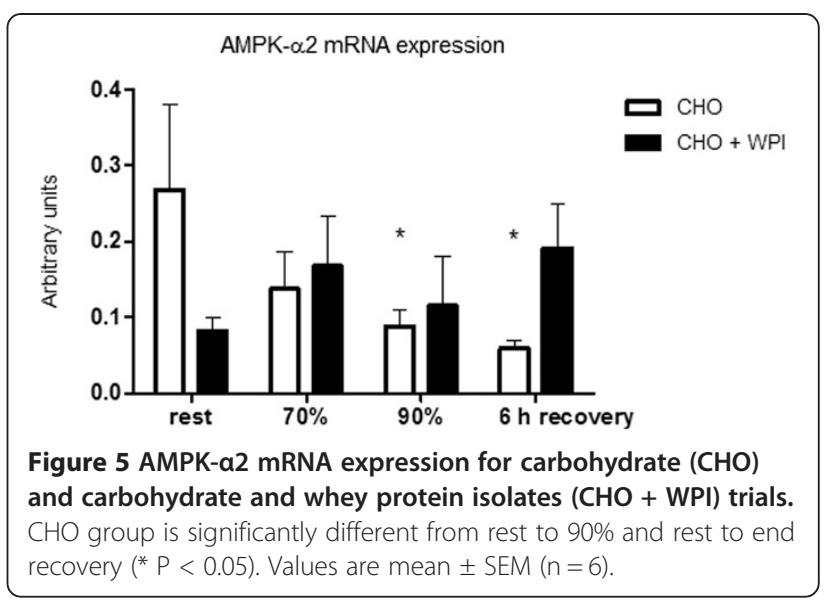

with the action of glycogen synthase [28,32]. Glycogen synthase mRNA expression was not increased in this study, indicative of a lack of stimulus for enhanced glycogen synthesis. However, the increased plasma insulin during recovery in the $\mathrm{CHO}+$ WPI trial may explain the enhanced recovery of muscle glycogen observed in the current study. The earlier reduction in plasma glucose concentration in the $\mathrm{CHO}+$ WPI trial (after $40 \mathrm{~min}$ ) compared to $\mathrm{CHO}$ alone (after $60 \mathrm{~min}$ ) supports this observation.

Insulin may also play a role in enhancing net protein balance by attenuating protein degradation [33]. Morrison et al. [34] examined the effect of endurance exercise and nutrition $(\mathrm{CHO}$, protein and $\mathrm{CHO}+$ protein) on the signal transduction pathways involved in mRNA translation; the mammalian target of rapamycin (mTOR) and three of its dependent signalling proteins: ribosomal protein s6 kinase- $1\left(\mathrm{p} 70^{\mathrm{s} 6 \mathrm{k}}\right)$, ribosomal protein $\mathrm{S6}$ (rps6) and

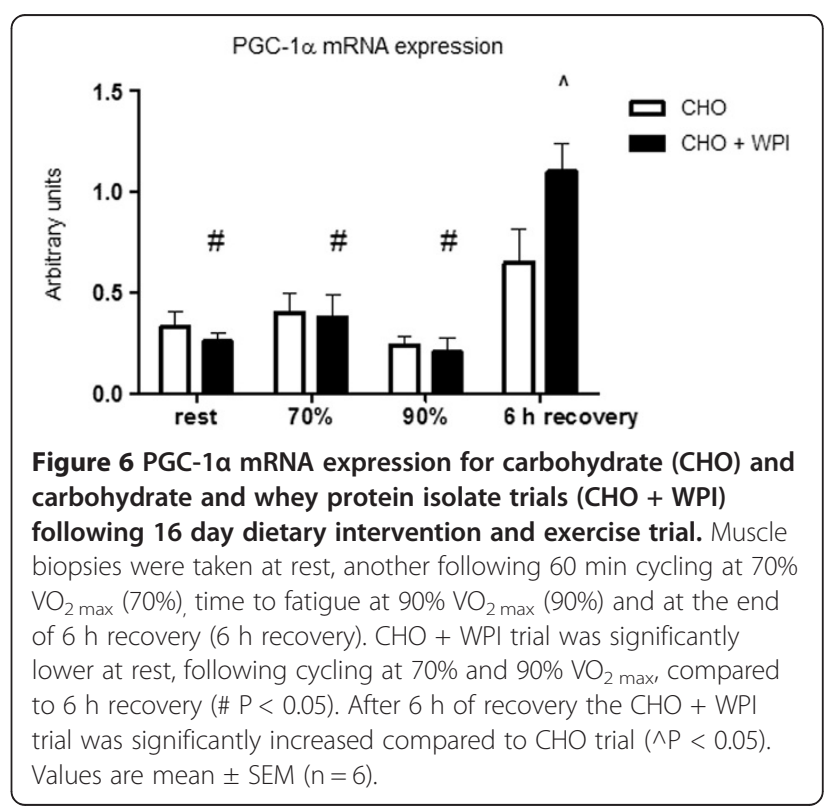


elongation initiation factor 4E binding protein-1 (4E-BP1). The $\mathrm{CHO}+$ protein group demonstrated increased plasma insulin and phosphorylated states of 4E-BP1 and rpS6 at 30 min post exercise, compared to the $\mathrm{CHO}$ and protein alone groups. mTOR is also involved in the activation of mitochondrial biogenesis [35]. These observations are in agreement with the current study which demonstrated an increased insulin response in the $\mathrm{CHO}+$ WPI trial, which may have played a role in the increased PGC- $1 \alpha$ mRNA expression observed.

Mitochondrial biogenesis is a well-established adaptation associated with endurance-type exercise [36], with PGC-1 $\alpha$ and AMPK important regulators of this process in skeletal muscle $[36,37]$. Changes in cellular energy status activate AMPK, which in turn phosphorylates PGC-1 $\alpha$ [36,38]. AMPK- $\alpha 2$ mRNA expression was decreased compared to rest in the $\mathrm{CHO}$ trial after cycling at $90 \% \mathrm{VO}_{2}$ max and $6 \mathrm{~h}$ recovery, although this was not different to the $\mathrm{CHO}+$ WPI trial.

PGC- $1 \alpha$ binds and co-activates a number of transcription factors from both the nuclear and mitochondrial genomes [36,39]. A single bout of physical activity has been shown to increase PGC- $1 \alpha$ mRNA in humans $[40,41]$. The results from the current study demonstrated co-ingestion of CHO + WPI elevated PGC- $1 \alpha$ mRNA expression compared to $\mathrm{CHO}$ at the end of the $6 \mathrm{~h}$ recovery period. This result may have important implications for consuming $\mathrm{CHO}+$ WPI with an endurance training program and enhancing muscle adaptations to training load. Numerous studies have investigated the effects of coingestion of carbohydrate and proteins during and after endurance-type exercise on protein synthesis rates and whole body protein balance $[42,43]$. However, these studies do not explore co-ingestion of $\mathrm{CHO}$ and proteins on signalling pathways involved in protein synthesis, in particular mitochondrial biogenesis signalling.

Breen et al. [44] investigated mitochondrial and myofibrillar muscle protein synthesis when carbohydrate or carbohydrate plus protein beverages were ingested following prolonged endurance cycling. This study found ingestion of carbohydrate plus protein increased myofibrillar but not mitochondrial muscle protein synthesis. This is in contrast to the current study, in which PGC- $1 \alpha$ mRNA increased with $\mathrm{CHO}+$ WPI compared to $\mathrm{CHO}$ alone. Aerobic exercise, such as the prolonged cycling performed in the study by Breen et al. [44], represents a stimulus that would elicit adaptations such as mitochondrial biogenesis and mitochondrial protein synthesis, in which PGC- $1 \alpha$ is considered a master regulator. The current study investigated mRNA 6 hours post exercise, whereas Breen et al. [44] measured protein synthesis 4 hours post exercise. The latter time point may be too soon after exercise and consumption of $\mathrm{CHO}$ plus protein beverage, to see an increase in mitochondrial proteins [36]. It is important to note, the current study included 2 weeks of dietary control and supplementation prior to the exercise trial and the Breen et al. [44] study only supplemented post exercise. The $\mathrm{CHO}$ intake of the trained cyclist in the Breen et al. [44] study was $5 \mathrm{~g} \cdot \mathrm{kg}^{-1}$ body weight $\cdot \mathrm{d}^{-1}$, this is below current recommendations for athletes [45], whereas the current study used $8 \mathrm{~g} \cdot \mathrm{kg}^{-1}$ body weight $\cdot \mathrm{d}^{-1}$, which may have also resulted in the different observations in these studies.

\section{Conclusions}

Our study demonstrated a 2-week dietary intervention of co-ingestion $\mathrm{CHO}+\mathrm{WPI}$, had positive effects on aspects of endurance adaptations at the end of $6 \mathrm{~h}$ recovery, following an exercise bout. Muscle glycogen levels were not further increased pre exercise, however with WPI supplementation; there was enhanced recovery from $90 \% \mathrm{VO}_{2}$ max cycling to end $6 \mathrm{~h}$ recovery. Plasma insulin levels were increased with $\mathrm{CHO}+$ WPI during the recovery phase. PGC- $1 \alpha$ mRNA was increased at the end of $6 \mathrm{~h}$ recovery following ingestion of $\mathrm{CHO}+$ WPI. Co-ingestion of $\mathrm{CHO}+$ WPI therefore appears to play an important role in endurance training adaptations via increasing plasma insulin and PGC- $1 \alpha$ mRNA expression during recovery which may lead to enhanced recovery, mitochondrial biogenesis and thus ultimately performance.

\section{Abbreviations}

WPI: Whey protein isolates; CHO: Carbohydrate; PGC-1a: Peroxisome proliferator-activated receptor gamma coactivator-1 alpha; MPS: Muscle protein synthesis; W: Watts; HR: Heart rate; mRNA: Messenger RNA; AMPK-a2: Adenosine monophosphate-activated protein kinase-alpha 2; SEM: Standard error of the mean.

\section{Competing interests}

This work has been supported in part by MG Nutritionals, Melbourne, Australia. The authors declare no other competing interest.

\section{Authors' contributions}

$\mathrm{KH}, \mathrm{CGS}, \mathrm{EG}, \mathrm{AH}$ and $\mathrm{AM}$ developed the study design. $\mathrm{KH}$ was in charge of subject recruitment, data collection and management, statistical analysis. EG was responsible for carrying out mRNA expression analysis. CGS, AH and AM participated in data collection. All authors contributed to drafting of the manuscript. All authors have read and approved the final manuscript.

\section{Acknowledgments}

The authors thank Tracey Gerber, Dee Horvath, Jess Ellis, Bradley Gatt and Jess Meilak for their helpful advice and technical assistance. This work was supported by 01/09 CRGS The Faculty of Health, Engineering \& Science Collaborative Research Grants Scheme, Victoria University, Melbourne, Australia (AJM and CGS) and through the Australian Government's Collaborative Research Networks (CRN) program (AJM, CGS and AH).

Received: 13 September 2012 Accepted: 7 February 2013

Published: 12 February 2013

\section{References}

1. Rodriguez N, Vislocky L, Gaine P: Dietary protein, endurance exercise, and human skeletal-musvercle protein turn. Curr Opin Clin Nutr 2007, 10:40-45. 2. Hawley J, Tipton K, Millard-Stafford M: Promoting training adaptations through nutritional interventions. J Sport Sci 2006, 24(7):709-721.

3. Ivy J: Regulation of muscle glycogen repletion, muscle protein synthesis and repair following exercise. J Sports Sci Med 2004, 3:131-138. 2004. 
4. Ha E, Zemel M: Functional properties of whey, whey components, and essential amino acids: mechanisms underlying health benefits for acticve people. J Nutr Biochem 2003, 14:251-258.

5. Cox GR, Clark SA, Cox AJ, Halson SL, Hargreaves M, Hawley JA, Jeacocke N, Snow RJ, Yeo WK, Burke LM: Daily training with high carbohydrate availability increases exogenous carbohydrate oxidation during endurance cycling. J App/ Physiol 2010, 109(1):126-134.

6. Rowlands D, Thorp R, Rossler K, Graham D, Rockell M: Efect of protein-rich feeding on recovery after intense exercise. Int J Sport Nutr Exerc Metab 2007, 17:521-543.

7. Jentjens $R$, Jeukendrup A: Determinants of post exericse glycogen synthesis during short term recovery. Sports Med 2003, 33(2):117-144.

8. Rauch $H$, Gibson A, Lambert E, Noakes T: A signalling role for muscle glycogen in the regulation of pace during prolonged exercise. Brit J Sport Med 2005, 39:34-38.

9. Westerblad H, Bruton JD, Katz A: Skeletal muscle: energy metabolism, fiber types, fatigue and adaptability. Exp Cell Res 2010, 316(18):3093-3099.

10. Kerksick C, Harvey T, Stout J, Campbell B, Wilborn C, Kreider R, Kalman D, Ziegenfuss T, Lopez H, Landis J, Ivy JL, Antonio J: International Society of Sports Nutrition position stand: nutrient timing. J Int Soc Sports Nutr 2008, 5:17.

11. Maughan R: Nutritional status, metabolic responses to exercise and implications for performance. Biochem Soc 2003, 31(6):1267-1269.

12. Hawley JA, Burke LM, Phillips SM, Spriet LL: Nutritional modulation of training-induced skeletal muscle adaptations. J Appl Physio/ 2011, 110(3):834-845.

13. Smith T, Montain S, Anderson D, Young A: Plasma amino acid responses after consumption of beverages with varying protein type. Int J Sport Nutr Exerc Metab 2009, 19:1-17.

14. Tang JE, Moore DR, Kujbida GW, Tarnopolsky MA, Phillips SM: Ingestion of whey hydrolysate, casein, or soy protein isolate: effects on mixed muscle protein synthesis at rest and following resistance exercise in young men. J Appl Physiol 2009, 107(3):987-992.

15. Tipton K, Wolfe R: Protein and amino acids for athletes. J Sport Sci 2004, 22:65-79.

16. Wilkinson SB, Phillips SM, Atherton PJ, Patel R, Yarasheski KE, Tarnopolsky $M A$, Rennie MJ: Differential effects of resistance and endurance exercise in the fed state on signalling molecule phosphorylation and protein synthesis in human muscle. J Physiol 2008, 586(Pt 15):3701-3717.

17. Camera DM, Edge J, Short MJ, Hawley JA, Coffey VG: Early time course of Akt phosphorylation after endurance and resistance exercise. Med Sci Sports Exerc 2010, 42(10):1843-1852.

18. Walker D, Dickinson J, Timmerman K, Drummond M, Reidy P, Fry C, Gundermann D, Rasmussen B: Exercise, amino acids, and ageing in the control of human muscle protein synthesis. Med Sci Sports Exerc 2011, published ahead of Print

19. Cribb PJ, Williams AD, Carey MF, Hayes A: The effect of whey isolate and resistance training on strength, body composition, and plasma glutamine. Int J Sport Nutr Exerc Metab 2006, 16(5):494-509.

20. Hulmi JJ, Lockwood CM, Stout JR: Effect of protein/essential amino acids and resistance training on skeletal muscle hypertrophy: A case for whey protein. Nutr Metab (Lond) 2010, 7:51.

21. Jentjens $R L$, van Loon $L$, Mann $C H$, Wagenmakers $A J$, Jeukendrup $A E$ : Addition of protein and amino acids to carbohydrates does not enhance postexercise muscle glycogen synthesis. J Appl Physiol 2001 91(2):839-846

22. Evans WJ, Phinney SD, Young VR: Suction applied to a muscle biopsy maximizes sample size. Med Sci Sports Exerc 1982, 14(1):101-102.

23. Lowry O, Passonneau J: A flexible system of enzymatic analysis. New York: Academic; 1972

24. Livak KJ, Schmittgen TD: Analysis of relative gene expression data using real-time quantitative PCR and the 2(-Delta Delta $C(T))$ Method. Methods 2001, 25(4):402-408

25. Madsen K, Pedersen PK, Rose P, Richter EA: Carbohydrate supercompensation and muscle glycogen utilization during exhaustive running in highly trained athletes. Eur J Appl Physiol Occup Phys 1990, 61(5-6):467-472

26. IVy J, Goforth HJ, Damon B, McCauley T, Parsons E, Price T: Early post exercise muscle glycogen recovery is enhanced with a carbohydrate-protein supplement. J Appl Physiol 2002, 93:1337-1344.
27. Van Loon L, Saris W, Kruijshoop M, Wagenmeakers A: Maximising postexercise muscle glycogen synthesis: carbohydrate supplementation and the aplication of amino acid or protein hydrolysate mixtures. Am J Clin Nutr 2000, 72:106-111.

28. Zawadzki K, Yaspelkis B, Ivy J: Carbohydrate-protein complex increases the rate of muscle glycogen storage after exercise. J Appl Physiol 1992, 72:1854-1859.

29. Nilsson M, Holst J, Bjorck I: Metabolic effect of amino acid mixtures and whey protein in healthy subjects: studis using glucose equivalent drinks. Am J Clin Nutr 2007, 85:996-1004.

30. Power $\mathrm{O}$, Hallihan A, Jakeman P: Human insulinotropic response to oral ingestion of native and hydrolysed whey protein. Amino Acids 2009, 37:333-339.

31. Claessens M, Saris W, Van Baak M: Glucagon ad insulin responses after ingestion of different amounts of intact and hydrolysed proteins. Brit J Nutr 2008, 100:61-69.

32. Van Loon $L$, Saris $W$, Verhagen $H$, Wagenmakers A: PLasma insulin responses following the ingestion of different amino acid/protein carbohydrate mixtures. Am J Clin Nutr 2000, 72:96-105.

33. Rowlands DS, Thomson JS, Timmons BW, Raymond F, Fuerholz A, Mansourian R, Zwahlen MC, Metairon S, Glover E, Stellingwerff T, Kussmann M, Tarnopolsky MA: Transcriptome and translational signaling following endurance exercise in trained skeletal muscle: impact of dietary protein. Physiol Genomics 2011, 43(17):1004-1020.

34. Morrison PJ, Hara D, Ding Z, Ivy JL: Adding protein to a carbohydrate supplement provided after endurance exercise enhances 4E-BP1 and RPS6 signaling in skeletal muscle. J App/ Physio/ 2008, 104(4):1029-1036.

35. Cunningham JT, Rodgers JT, Arlow DH, Vazquez F, Mootha VK, Puigserver P: mTOR controls mitochondrial oxidative function through a YY1-PGC -1alpha transcriptional complex. Nature 2007, 450(7170):736-740.

36. Hood DA: Mechanisms of exercise-induced mitochondrial biogenesis in skeletal muscle. Appl Physiol Nutr Metab 2009, 34(3):465-472.

37. Lin J, Handschin C, Spiegelman BM: Metabolic control through the PGC-1 family of transcription coactivators. Cell Metab 2005, 1(6):361-370.

38. Irrcher I, Adhihetty PJ, Joseph AM, Ljubicic V, Hood DA: Regulation of mitochondrial biogenesis in muscle by endurance exercise. Sports Med 2003, 33(11):783-793.

39. Koulmann N, Bigard AX: Interaction between signalling pathways involved in skeletal muscle responses to endurance exercise. Pflugers Arch 2006, 452(2):125-139.

40. Akimoto T, Pohnert SC, Li P, Zhang M, Gumbs C, Rosenberg PB, Williams RS, Yan Z: Exercise stimulates Pgc-1alpha transcription in skeletal muscle through activation of the p38 MAPK pathway. J Biol Chem 2005, 280(20):19587-19593.

41. Baar K, Wende AR, Jones TE, Marison M, Nolte LA, Chen M, Kelly DP, Holloszy JO: Adaptations of skeletal muscle to exercise: rapid increase in the transcriptional coactivator PGC-1. FASEB J 2002, 16(14):1879-1886.

42. Koopman R, Pannemans D, Jeukendrup A, Gijsen A, Senden J, Halliday D, Saris W, Van Loon L, Wagenmakers A: Combined ingestion of protein and carbohydrate improves protein balance. Am J Physiol Endocrinol and Metab 2004, 287:E712-E720.

43. Beelen M, Zorenc A, Pennings B, Senden J, Kuipers H, Van Loon L: Impact of protein coingestion on muscle protein synthesis during continuous endurance type exercise. Am J Physiol Endocrinol and Metab 2011, 300:E945-E954.

44. Breen L, Philp A, Witard OC, Jackman SR, Selby A, Smith K, Baar K, Tipton $\mathrm{KD}$ : The influence of carbohydrate-protein co-ingestion following endurance exercise on myofibrillar and mitochondrial protein synthesis. J Physiol 2011, 589(Pt 16):4011-4025.

45. Rodriguez NR, Di Marco NM, Langley S: American College of Sports Medicine position stand. Nutrition and athletic performance. Med Sci Sports Exerc 2009, 41(3):709-731.

doi:10.1186/1550-2783-10-8

Cite this article as: Hill et al:: Co-ingestion of carbohydrate and whey protein isolates enhance PGC-1 a mRNA expression: a randomised, single blind, cross over study. Journal of the International Society of Sports Nutrition 2013 10:8. 